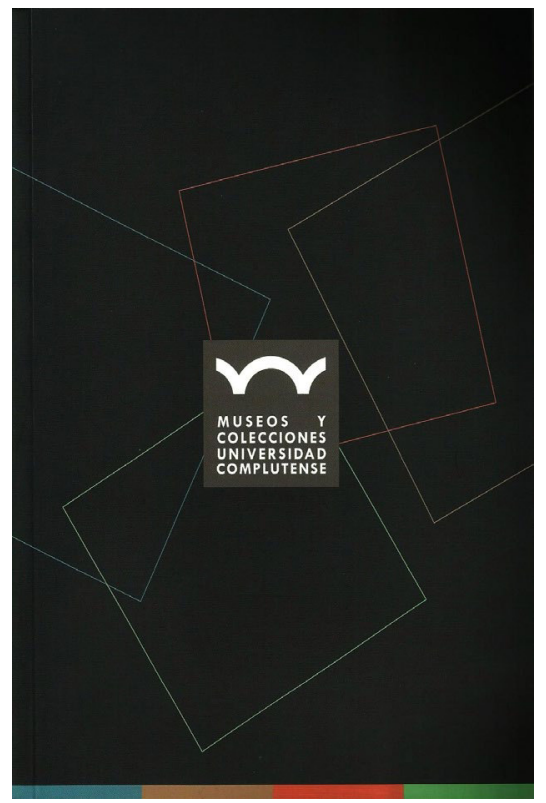

\section{Museos y colecciones de la Universidad Complutense} de Madrid

Editado por: la Universidad Complutense de Madrid. Vicerrectorado de Extensión Universitaria, Cultura y Deporte, Madrid. 2015

Páginas: 167

Idioma: Español

ISBN: 978-84-96701-69-4
En los últimos diez años se han publicado documentos fundamentales relacionados con los museos y colecciones universitarias; además, se han llevado a cabo iniciativas a nivel nacional, europeo e internacional que han buscado respaldar, dar a conocer y poner en valor el Patrimonio universitario, tan significativo y a la vez, tan ignorado.

En 2005 se publicó la conocida Recomendación $\operatorname{Rec}(2005) 13$ del Consejo de Europa sobre el gobierno y gestión del patrimonio universitario. En este documento se pide que los museos y colecciones definan sus objetivos y sus políticas, que hagan accesibles el patrimonio a los miembros de la comunidad académica y al público en general; además se insta a tomar las medidas apropiadas para salvaguardar y proteger el patrimonio, incluyendo la propuesta de que las universidades deben promover y desarrollar los métodos adecuados para fomentar el valor, la naturaleza y el interés del patrimonio actual.

Diez años más tarde, en 2015 se publica el documento más reciente: la Declaración de México sobre protección, conservación y difusión del Patrimonio, las colecciones y los museos universitarios; este documento se firmó el 22 de septiembre de 2015 y ha sido suscrito por cuatro universidades iberoamericanas históricas que poseen un destacado patrimonio histórico. En ella, como antes se había hecho en la llamada Declaración de Salamanca sobre el Patrimonio histórico-cultural de las universidades de 2008, se pone de manifiesto la importancia del Patrimonio cultural universitario material e inmaterial y la necesidad de protegerlo, conservarlo y difundirlo existiendo un compromiso por alcanzar el reconocimiento social de las instituciones académicas y compartir el conocimiento con otras universidades, buscando la colaboración y la cooperación internacional.

La Universidad Complutense de Madrid a través de la publicacion de la guía de sus museos y colecciones ha respondido a uno de los objetivos fundamentales que marcó la Recomendación del Consejo de Europa antes citada: preparar una publicación sobre la historia y significación de las colecciones; además ha contribuido de manera significativa a las proposiciones hechas por las documentos antes reseñados. La confección de la Guía ha sido un logro muy destacable por su relevancia, importancia y oportunidad. Este proyecto ha supuesto una labor notable de coordinación llevada a cabo bajo la dirección de Dña. Margarita San Andrés Moya, quien fue Vicerrectora de Extensión Universitaria, Cultura y Deporte de la UCM, y se ha hecho realidad gracias al apoyo de la Unidad de Gestión de Patrimonio Histórico de la Universidad y de los directores y responsables de los museos y colecciones que han colaborado de manera entusiasta.

La plural diversidad de los orígenes de los museos y colecciones de la UCM da muestra de la riqueza de unos fondos que pocas universidades poseen: 14 museos y 15 colecciones que aglutinan el saber en los diferentes campos científicos a los que se une una magnífica colección artística. Los objetos y 
especímenes fueron en su mayoría reunidos con un fin docente y de investigación, pero hoy han pasado a formar parte de un patrimonio histórico, cultural, científico y artístico que es necesario conservar y difundir de la mejor manera posible porque forman parte de la memoria colectiva, que no se debe perder. En el pasado hubo publicaciones que dieron a conocer parte de los fondos de la Universidad y que son todavía una referencia para su estudio; sin embargo, esta guía tiene la virtud de recoger de manera sistemática los datos de todos los museos y colecciones existentes y hacerlos accesibles para su consulta. Este proyecto es un ejemplo de sistematización y normalización de la información, para ello se ha diseñado y desarrollado una identidad gráfica que aglutina, y a la vez distingue, a las colecciones; de ellas se incluye una breve historia y una descripción general de sus fondos ilustrada con imágenes de gran calidad. Los museos y colecciones están organizados por colores según la temática de sus contenidos y al final de la publicación se incluye un índice de referencias de las ilustraciones que aparecen. Hay que destacar asimismo, el diseño de la guía que posee un formato muy apropiado, accesible y manejable.

Podemos concluir apuntando que este es un paso fundamental para el conocimiento de un patrimonio muy destacado, se ha logrado crear una herramienta que debe servir para seguir avanzando en su difusión y en la conexión con otras instituciones patrimoniales con las que comparte valores, objetivos y funciones.

Isabel M. García Fernández

Facultad de Bellas Artes. UCM 